Proc. Estonian Acad. Sci. Geol., 1999, 48, 2, 86-98

\title{
MIOSPORE ASSEMBLAGE FROM THE LODE MEMBER (GAUJA FORMATION) IN ESTONIA AND THE MIDDLE-UPPER DEVONIAN BOUNDARY PROBLEM
}

\author{
Elga MARK-KURIK ${ }^{\mathrm{a}}$, Alain BLIECK ${ }^{\mathrm{b}}$, Stanislas LOBOZIAK ${ }^{\mathrm{b}}$, \\ and Anne-Marie CANDILIER ${ }^{\mathrm{b}}$
}

${ }^{a}$ Institute of Geology, Tallinn Technical University, Estonia pst. 7, 10143 Tallinn, Estonia; kurik@gi.ee

b Université des Sciences et Techniques de Lille, Sciences de la Terre, URA 1365 du CNRS, F-59655 Villeneuve d'Ascq cedex, France; Alain.Blieck@univ-lille1.fr

Received 12 October 1998

\begin{abstract}
A miospore assemblage, equivalent to that of the Ancyrospora incisa-Geminospora micromanifesta (IM) Subzone of the East European Platform, was identified in a sample from the old refractory clay quarry at Küllatova, SE Estonia. It permits us to correlate the Gauja Formation of the Baltic area with probable coeval stratigraphic units in the adjacent regions - Belarus and the Moscow Basin. The Middle-Upper Devonian boundary probably lies close to, but somewhat above, the top of the Gauja Formation.
\end{abstract}

Key words: miospores, biostratigraphy, Middle-Upper Devonian boundary, Estonia, Baltic area.

\section{INTRODUCTION}

The Devonian series of the Main Devonian Field, on the eastern side of the Baltic Sea (northwestern subregion of the East European, or Russian, Platform), includes subsurface Lower Devonian deposits as well as subsurface and outcrop Middle and Upper Devonian strata. It is a classical series for the Devonian of Europe, which has been particularly well studied for its fossil vertebrate fauna including over 250 different species. All higher groups of Devonian agnathan and gnathostome vertebrates of the Old Red Sandstone Continent are recorded 
in this series. Vertebrates form palaeocommunities which are dominated by agnathans in the Lower Devonian, by placoderms in the Middle Devonian, and by placoderms plus sarcopterygians in the Upper Devonian (Blieck et al., 1988; Janvier \& Blieck, 1993).

The vertebrate biozonation of the East Baltic Devonian series is based upon both agnathans (thelodont microremains and heterostracan pteraspidomorph macroremains) and gnathostomes (acanthodian microremains and placoderm macroremains) (Karatajūtè-Talimaa, 1978; Lyarskaya, 1978, 1981; Sorokin, 1981; Lyarskaya \& Lukševičs, 1992; Mark-Kurik, 1991, 1995, 1997, in press; Valiukevičius, 1994; Lukševičs, 1996; Lukševičs \& Ivanov, 1996). However, the troublesome dating of that series in terms of the standard Devonian conodont biozonation (Mark-Kurik, 1996; Sorokin, 1996) remains largely unsolved. Tentative correlations have been worked out during several years by the IUGS Subcommission on Devonian Stratigraphy (SDS) and in connection with the IUGS-IGCP project 328 on Palaeozoic microvertebrates. Our paper represents one step towards the solution of the particular problem, viz., the identification of the Middle-Upper Devonian boundary.

\section{STRATIGRAPHIC SETTING}

Of the entire Devonian series in the Baltic area [Baltic States and neighbouring regions of the CIS (former USSR)], only a few horizons have yielded conodonts. This is certainly due to the unsuitable lithofacies, which are mainly composed of siliciclastics (see, e.g., Kleesment, 1995 for the interval studied here). Conodont biozones have been defined for regional equivalents of the lower Lochkovian (woschmidti Zone from the Brest depression of Belarus), the uppermost Eifelian (kockelianus Zone from the Kernave Regional Substage), the lower Frasnian (asymmetricus Zone in the Plavinas Regional Stage), and the Famennian [from the gigas (?) to the lower costatus (?) zones] (Žeiba \& Valiukevičius, 1972; Žeiba, 1994; Valiukevičius, 1994; review in Blieck et al., in press). According to the current standard conodont zonation (Clausen et al., 1993), the asymmetricus Zone corresponds to the interval ranging from the falsiovalis to lower hassi zones.

In order to solve the problem of conodont biozone correlation, miosporebased investigations have been carried out through nearly the whole series, with particular attention to the late Emsian-early Famennian interval (Vaitiekūnienè in Narbutas et al., 1993; Valiukevičius, 1994; Kõrts \& Mark-Kurik, 1997). However, the comparison of East Baltic miospore data with palynozonal schemes of the Central Devonian Field (central subregion of the East European Platform) (Avkhimovitch et al., 1993) and the Ardenne-Rhenish type regions of western Europe (Streel et al., 1987) turned out problematic too (Blieck et al., in press). 
The aim of the present study is to review the proposed correlations in the light of our miospore results from the Middle Devonian series with reference to the Middle and Upper Devonian miospore zones of Eastern Europe, which are reliably dated by conodonts (Avkhimovitch et al., 1993, fig. 4).

\section{SAMPLING AND STUDY AREA}

One of us (E. M.-K.) obtained several samples from the Devonian series of SE Estonia and adjacent areas - Latvia and Pskov District of Russia. Eleven samples in the collections of the Institute of Geology, Tallinn, and Geological Museum of the University of Tartu are from the Gauja, Amata, and Plavinas formations (Snetnaya Gora and Pskov beds). These units encompass the stratigraphical interval where the Middle-Upper Devonian boundary is classically placed in the Baltic area (Mark-Kurik, 1993, 1996; Lukševičs \& Ivanov, 1996; Sorokin, 1996). Unfortunately, of all studied samples, only one contained miospores. It comes from the Lode Member of the Gauja Formation at Küllatova, SE of Tartu, near the Russian border (Fig. 1).

In an attempt at more accurate biostratigraphical results, a second sample was processed for palynomorphs. It is from the Abava Beds of the Givetian Burtnieki Formation, exposed at Joosu refractory clay quarry in SE Estonia. This locality has yielded a quite rich fish assemblage, including Psammosteus, Actinolepis, Watsonosteus, etc. (Mark-Kurik, 1997) and macroremains of the pteridophyte plant Pseudosporochnus estonicus (Kalamees, 1988). However, the Joosu sample contained only small, coalified, opaque organic fragments and very rare, lightyellow but corroded miospores. Most of these are morphologically simple and have no biochronostratigraphic significance. Besides, the co-occurrence of Geminospora lemurata and Samarisporites sp. cf. S. triangulatus, two Middle Devonian key-species ranging from the late early Givetian to the earliest Famennian, has no bearing on the location of the Givetian-Frasnian boundary. Hence, we will focus on the miospore content of the Küllatova sample only.

This sample is from a long abandoned refractory clay quarry, which before World War II was operated by the "Eesti Schamott" company. The rock succession at Küllatova is roughly equivalent to that of Lode clay quarry near Liepa village in Latvia. Lode quarry is famous for its rich fish assemblage, including numerous articulated specimens of Asterolepis, Panderichthys, and Laccognathus (see, e.g., Lyarskaya, 1981; Mark-Kurik et al., 1989).

Küllatova is mainly known for its fossil flora, which, according to Thomson (1940), contains miospores and plant remains attributed to "Hostimella" sp. (now Hostinella). From this locality as well as from Lode quarry were also identified Archaeopteris sp. and A. fissilis (Yurina, 1988). Both the Lode and Küllatova intervals correspond to the upper part of the Gauja Formation, i.e., to a section within the Lode Member (Kuršs, 1992; Kleesment, 1995; Kleesment \& MarkKurik, 1997). 


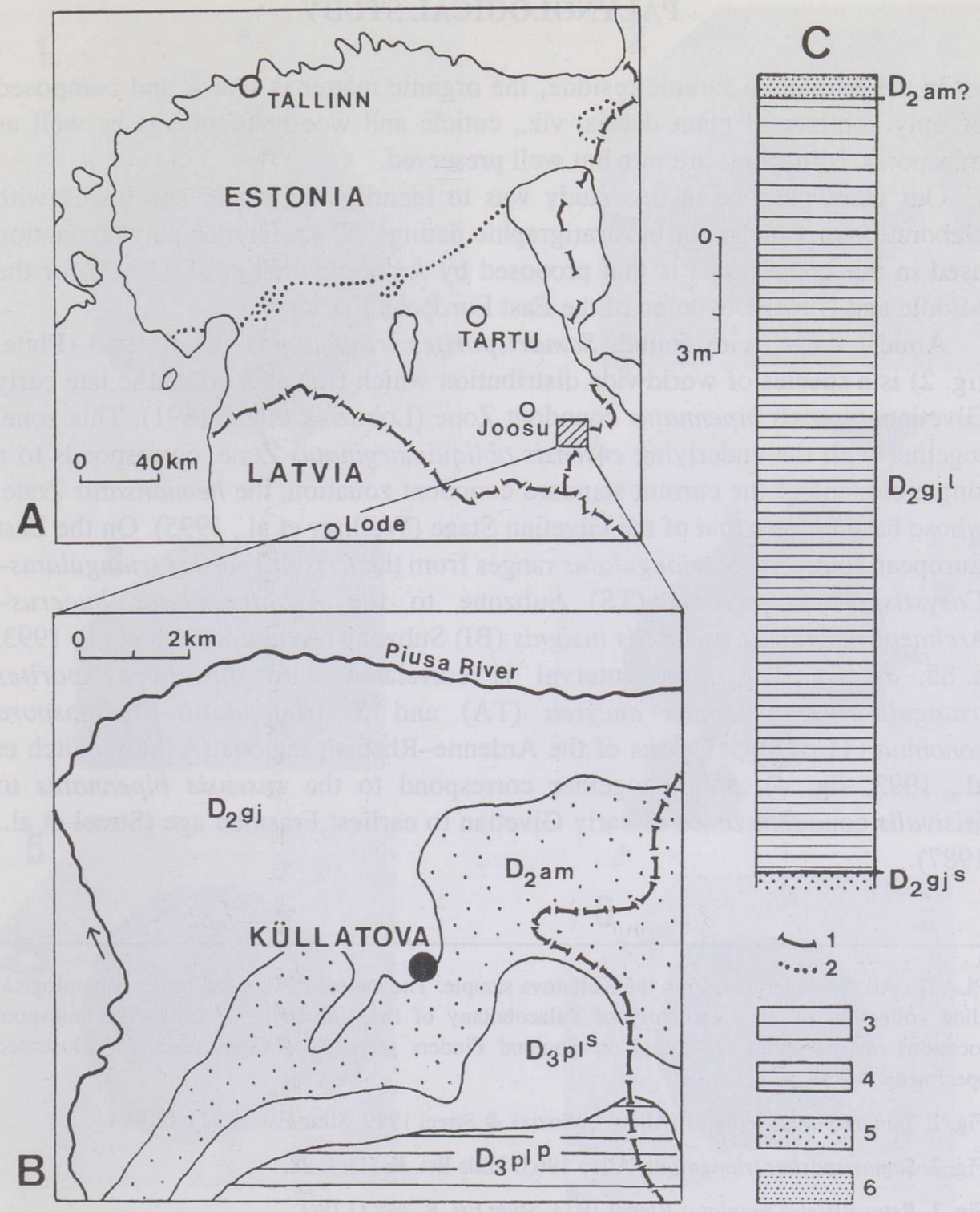

Fig. 1. Geographical and geological context of fossiliferous localities of the Gauja and surrounding formations in South Estonia and North Latvia. (A) Location map. (B) Bedrock sketch-map of the middle course region of the Piusa River (modified after Kajak, 1997). (C) Stratigraphical column of the Küllatova section (modified after Steinmann \& Sarv, 1951): 1, frontier; 2, northern limit of the distribution area of the Devonian rocks; 3, light-grey clay; 4, dark-grey clay; 5 , light-brown sandstone; 6 , greenish-grey sandstone. Stratigraphical indices: $\mathrm{D}_{2} \mathrm{gj}$, Gauja Formation; $\mathrm{D}_{2} \mathrm{gj}^{\mathrm{s}}$, Sietini Member of the Gauja Formation; $D_{2} g^{1}$, Lode Member of the Gauja Formation; $D_{2} a m$, Amata Formation; $\mathrm{D}_{3} \mathrm{pl}^{\mathrm{s}}$, Snetnaya Gora Beds of the Plavinas Formation; $\mathrm{D}_{3} \mathrm{pl}^{\mathrm{p}}$, Pskov Beds of the Plaviñas Formation. 


\section{PALYNOLOGICAL STUDY}

In the Küllatova sample residue, the organic matter is scarce and composed of only continental plant debris, viz., cuticle and woody fragments as well as miospores. Miospores are rare but well preserved.

Our main purpose in this study was to identify diagnostic specimens with elaborate morphology for biostratigraphic datings. The reference palynozonation used in our correlations is that proposed by Avkhimovitch et al. (1993) for the Middle and Upper Devonian of the East European Platform.

Amidst the species found, Samarisporites triangulatus Allen 1965 (Plate, fig. 2) is a species of worldwide distribution which first appears in the late early Givetian ensensis bipennatus conodont Zone (Loboziak et al., 1991). This zone, together with the underlying ensensis obliquimarginatus Zone, corresponds to a single biozone of the current standard conodont zonation, the hemiansatus Zone, whose base defines that of the Givetian Stage (Walliser et al., 1995). On the East European Platform, S. triangulatus ranges from the Cristatisporites triangulatusCorystisporites serratus (TS) Subzone to the Acanthotriletes bucerusArchaeozonotriletes variabilis insignis (BI) Subzone (Avkhimovitch et al., 1993, p. 85, fig. 3). The same interval is correlated with the Samarisporites triangulatus-Ancyrospora ancyrea (TA) and S. triangulatus-Chelinospora concinna (TCo) Oppel zones of the Ardenne-Rhenish regions (Avkhimovitch et al., 1993, fig. 4), which together correspond to the ensensis bipennatus to falsivalis conodont zones of early Givetian to earliest Frasnian age (Streel et al., 1987).

PLATE. All the material is from the Küllatova sample. The material is housed in the palynological slide collection of the Laboratory of Palaeobotany of the University of Lille. The miospore locations on the slides are based on England Finders graticules. Magnification of illustrated specimens: $\times 500$.

Fig. 1. Samarisporites eximius (Allen) Loboziak \& Streel 1989. Slide Est. K. (1): D 39/4.

Fig. 2. Samarisporites triangulatus Allen 1965. Slide Est. K. (1): L 28.

Fig. 3. Retusotriletes rugulatus Riegel 1973. Slide Est. K. (1): G 19/1.

Fig. 4. Ancyrospora sp. cf. Ancyrospora incisa (Naumova) Raskatova \& Obukhovskaya in Avkhimovitch et al., 1993. Slide Est. K. (2): L 41.

Fig. 5. Dictyotriletes sp. cf. Reticulatisporites perlotus (Naumova) Obukhovskaya in Avkhimovitch et al., 1993. Slide Est. K. (5): X 42/4.

Fig. 6. Geminospora micromanifesta (Naumova) Arkhangelskaya 1985. Slide Est. K. (1): R 23.

Fig. 7. Geminospora lemurata Balme emend. Playford 1983. Slide Est. K. (3): G 34/4.

Fig. 8. Perotrilites sp. cf. Rugospora? impolita (Naumova) Tchibrikova in Avkhimovitch et al., 1993. Slide Est. K. (4): T 47/1. 

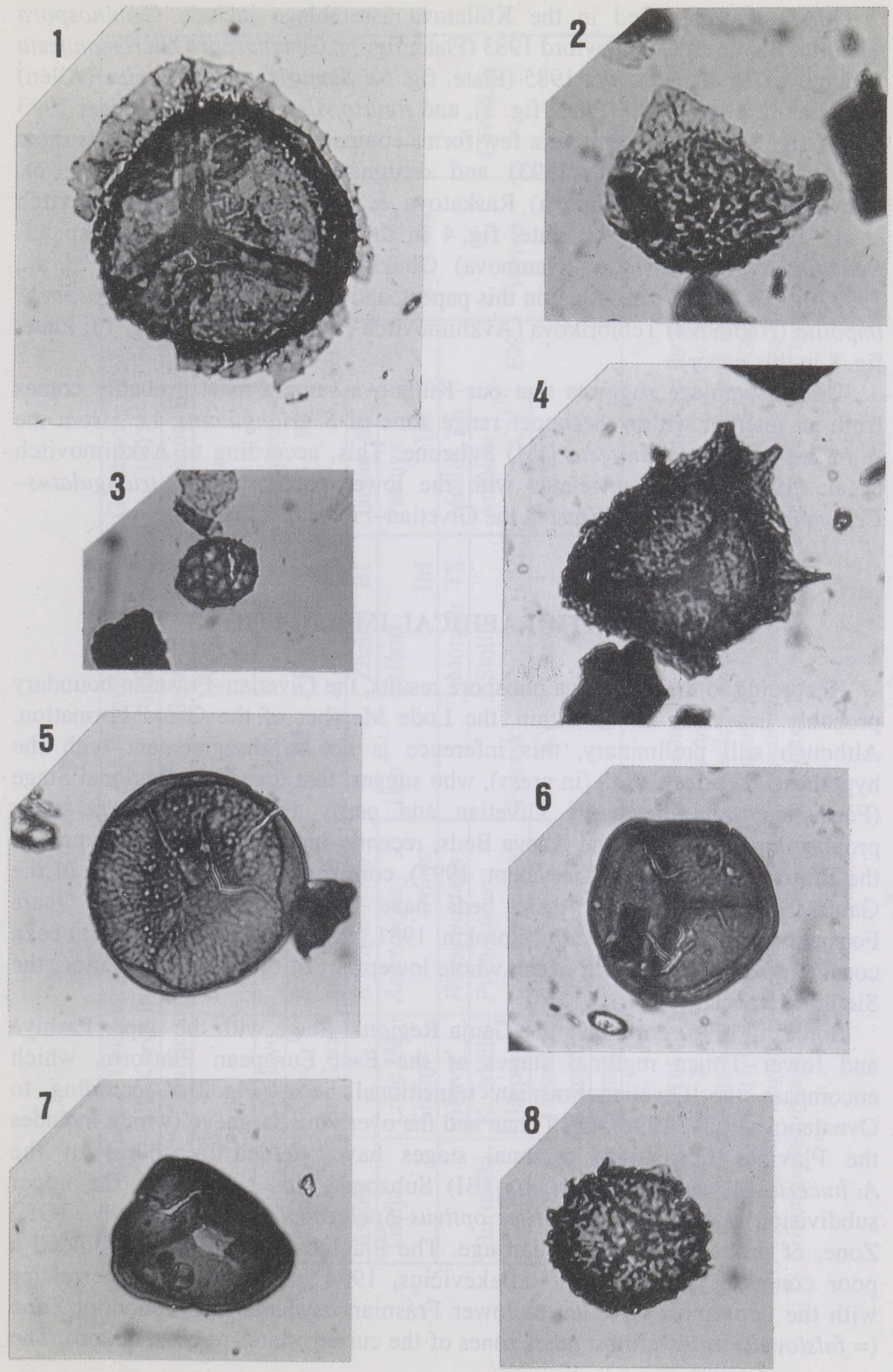
Other taxa identified in the Küllatova assemblage include Geminospora lemurata Balme emend. Playford 1983 (Plate, fig. 7), Geminospora micromanifesta (Naumova) Arkhangelskaya 1985 (Plate, fig. 6), Samarisporites eximius (Allen) Loboziak \& Streel 1989 (Plate, fig. 1), and Retusotriletes rugulatus Riegel 1973 (Plate, fig. 3). Also present are a few forms comparable to miospores illustrated by Avkhimovitch et al. (1993) and designated as Ancyrospora sp. cf. Ancyrospora incisa (Naumova) Raskatova \& Obukhovskaya (Avkhimovitch et al., 1993, pl. 10, fig. 1; Plate, fig. 4 in this paper), Dictyotriletes sp. cf. Reticulatisporites perlotus (Naumova) Obukhovskaya (Avkhimovitch et al., 1993, pl. 10, fig. 9; Plate, fig. 5 in this paper), and Perotrilites sp. cf. Rugospora? impolita (Naumova) Tchibrikova (Avkhimovitch et al., 1993, pl. 9, fig. 13; Plate, fig. 8 in this paper).

This assemblage suggests that our Küllatova sample most probably comes from an interval within the upper range zone of $S$. triangulatus, i.e., from the A. incisa-G. micromanifesta (IM) Subzone. This, according to Avkhimovitch et al. (1993, fig. 4), correlates with the lower part of the S.triangulatusC. concinna (TCo) Oppel Zone at the Givetian-Frasnian transition.

\section{BIOSTRATIGRAPHICAL IMPLICATIONS}

According to the Küllatova miospore results, the Givetian-Frasnian boundary probably lies close to, or within, the Lode Member of the Gauja Formation. Although still preliminary, this inference is not in disagreement with the hypothesis of Blieck et al. (in press), who suggest that the Gauja Regional Stage (Formation) may be partly Givetian and partly Frasnian. However, their proposition implies that the Abava Beds, recently included in the upper part of the Burtnieki Formation (Kleesment, 1995), correspond to the lower part of the Gauja Formation. Earlier, these beds have been included into the Gauja Formation as its basal part only (Sorokin, 1981, pp. 369, 372), and have not been considered as an equivalent of the whole lower part of the Gauja Formation, the Sietiņi Member.

Sorokin (1996) correlates the Gauja Regional Stage with the upper Pashiya and lower Timan regional stages of the East European Platform, which encompass the Givetian-Frasnian transitional beds (Fig. 2). According to Ovnatanova et al. (1996), the Timan and the overlying Sargaevo (which includes the Plavinas Formation) regional stages have yielded miospores of the A. bucerus - A. variabilis insignis (BI) Subzone. This subzone is the upper subdivision of the Contagisporites optivus-Spelaeotriletes krestovnikovii (OK) Zone, of probable early Frasnian age. The Plavinas Formation has yielded a poor conodont assemblage (Valiukevičius, 1994, p. 124), which correlates with the uppermost Givetian to lower Frasnian asymmetricus conodont Zone (= falsiovalis to lowermost hassi zones of the current standard biozonation). The 


\begin{tabular}{|c|c|c|c|c|c|c|c|c|c|c|}
\hline & & & 预 & & $\begin{array}{l}1 \\
1 \\
1 \\
1 \\
1\end{array}$ & & & 氖 & & \\
\hline 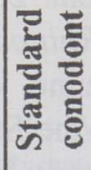 & है & & $\frac{\mathfrak{z}}{\vdots}$ & & & 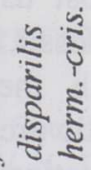 & & 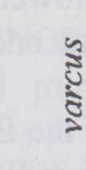 & & \\
\hline$\ddot{\grave{a}}$ & 등 & & & $\frac{1}{0}$ & & & & $\underset{I}{x}$ & & \\
\hline 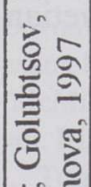 & ह & & 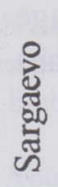 & 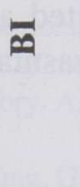 & 告 & 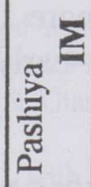 & 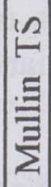 & 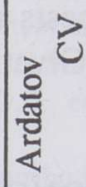 & 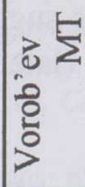 & \\
\hline 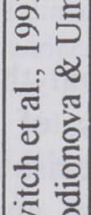 & 를 & 焉 & & సี & 흥 & $\begin{array}{l}2 \\
\text { 등 } \\
5 \\
5\end{array}$ & $\begin{array}{l}\tilde{n} \\
1 \\
\vdots \\
0 \\
0 \\
0 \\
\Sigma\end{array}$ & $\frac{\Xi}{\frac{0}{0}}$ & 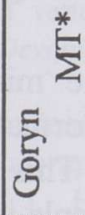 & \\
\hline 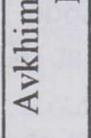 & & & 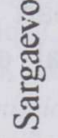 & 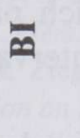 & & สี & & $\frac{\sqrt{5}}{0}$ & I & \\
\hline 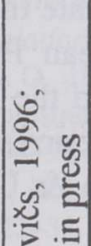 & F & 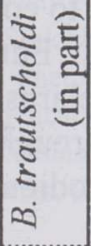 & & 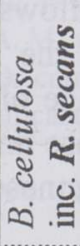 & 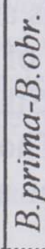 & 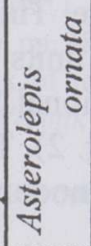 & 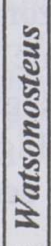 & 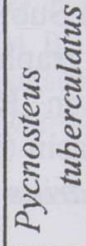 & 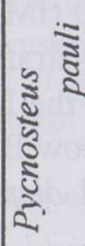 & $\begin{array}{l}\frac{a}{3} \\
\frac{\vdots}{3} \\
\frac{3}{5} \\
0 \\
2\end{array}$ \\
\hline 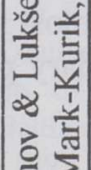 & 先 & & $\begin{array}{c}0 \\
0 \\
0 \\
0 \\
\Xi \\
\\
\end{array}$ & 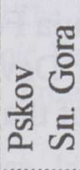 & & 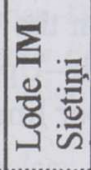 & 齐 & 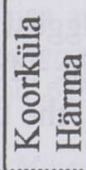 & 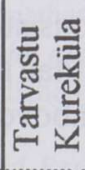 & 휵 \\
\hline 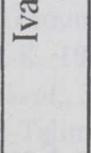 & & 音 & & 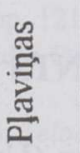 & 茎 & 茎 & & 曾 & $\frac{\text { 롤 }}{\text { 芑 }}$ & \\
\hline
\end{tabular}

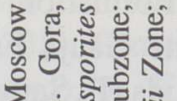

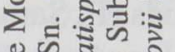
때 द

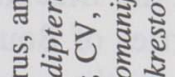

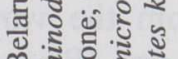

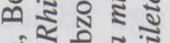
ฮึ่ ส ₹ $\frac{2}{3}$ ปี

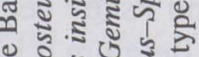
ฐ पर

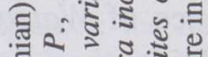

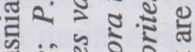

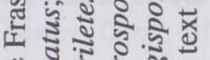

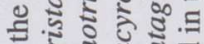
प. 들 ङ है ए००

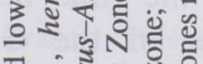
ㄷำ สิ ป็ ڤี

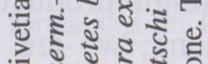

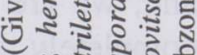
ส

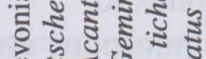

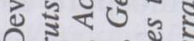
ำx

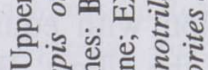
근ำ च के के है

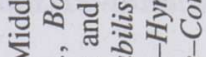
$\sum$ की 3 ป๐ำ पथ 든.

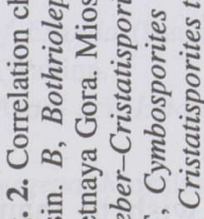

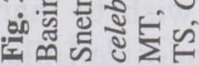


Plavinas Formation, as well as the underlying Amata Formation and the upper part of the Gauja Formation, are also dated to early Frasnian on the basis of brachiopods (P. Sartenaer, pers. comm. to A. Blieck., Tallinn, 1996).

The placoderm Watsonosteus, which characterizes the Abava Beds, is also known in the Blacourt and basal Beaulieu formations of Le Griset and Le Banc Noir quarries of Boulonnais, northern France (Lelièvre et al., 1988). These units range from the varcus to the lowermost asymmetricus conodont zones of Givetian age (Brice, 1988). A second fossil fish, the dipnoan Rhinodipterus secans, has been identified from both the Baltic and Ardenne (Namur Synclinorium, Belgium) areas. In the Baltic area the fish occurs in the Snetnaya Gora and Pskov beds of the Plavinuas Formation (Ivanov, 1990), of early Frasnian age. In Belgium it is known from the Mazy Member, in the upper part of the Bois de Bordeaux Formation, dated to late Givetian (Bultynck et al., 1991). So, the occurrence of Watsonosteus suggests a more limited age (late Givetian for the Abava Beds) than $R$. secans (late Givetian-early Frasnian).

\section{CONCLUSIONS}

For the time being, the miospore assemblage identified from the Lode Member of the Gauja Formation in the Baltic area is only of limited stratigraphical significance. This is because, on the one hand, the precise location of our single productive sample in the Küllatova section is not known, and on the other hand, we are still unable to determine which part of the Lode Member (more completely seen in Lode quarry) the interval exposed at Küllatova corresponds to.

The miospore assemblage in the Küllatova sample is similar to that of the A. incisa-G. micromanifesta (IM) Subzone. This allows us to correlate the Gauja Formation with equivalent stratigraphic units of the East European Platform, such as the Ubort' Beds of the Lan' Regional Stage of Belarus and the Pashiya Regional Stage of the Moscow Basin (Fig. 2). Those units roughly correspond to the hermanni-cristatus and disparilis conodont zones (Rodionova \& Umnova, 1997).

To sum up, our correlations suggest that the Gauja Formation is most likely of Middle Devonian age, and that the Middle-Upper Devonian boundary probably lies close to, but somewhat above, the upper limit of that formation.

\section{ACKNOWLEDGEMENTS}

We wish to thank R. Coquel and J. Carpentier (Université des Sciences et Techniques de Lille, Sciences de la Terre) who assisted in making the slides and photographs of the spores, and K. Ronk (Institute of Geology, Tallinn) for the 
drawing. E. Mark-Kurik acknowledges financial support of the Estonian Science Foundation (grant 3499) and NATO (grant OUTR.LG 961235). Our thanks go to J. H. G. de Melo (PETROBRAS/CENPES, Rio de Janeiro), A. Kleesment (Institute of Geology, Tallinn), and V. Karatajūtè-Talimaa (Institute of Geology, Vilnius) who reviewed the manuscript.

\section{REFERENCES}

Avkhimovitch, V. I., Tchibrikova, E. V., Obukhovskaya, T. G., Nazarenko, A. M., Umnova, V. T., Raskatova, L. G., Mantsurova, V. N., Loboziak, S. \& Streel, M. 1993. Middle and Upper Devonian miospore zonation of Eastern Europe. Bull. Centres Rech. Explor.-Prod. Elf Aquitaine, 17, 1, 79-147.

Blieck, A., Mark-Kurik, E. \& Märss, T. 1988. Biostratigraphical correlations between SiluroDevonian invertebrate-dominated and vertebrate-dominated sequences: the East Baltic example. In Devonian of the World. Proc. II Int. Symp. Devonian System, Calgary, 1987 (McMillan, N. J., Embry, A. F. \& Glass, D. J., eds.). Can. Soc. Petrol. Geol., Mem., 14, vol. III, 579-587.

Blieck, A., Turner, S. \& Young, G. C., with contributions of Lukševičs, E., Mark-Kurik, E., Talimaa, V. N. \& Valiukevičius, J. J. Devonian vertebrate biochronology and global marine/non-marine correlation. In International Devonian Correlation. Courier Forsch.Inst. Senckenberg (in press).

Brice, D. (ed.). 1988. Le Dévonien de Ferques, Bas-Boulonnais (N. France). PaléontologieSédimentologie-Stratigraphie-Tectonique. Biostratigraphie du Paléozoïque, 7.

Bultynck, P., Coen-Aubert, M., Dejonghe, L., Godefroid, J., Hance, L., Lacroix, D., Préat, A., Stainier, P., Steemans, P., Streel, M. \& Tourneur, F. 1991. Les formations du Dévonien moyen de la Belgique. Mém. Explic. Cartes Géol. min. Belg., 30.

Clausen, C.-D., Weddige, K. \& Ziegler, W. 1993. Devonian of the Rhenish Massif. Newsletter I.U.G.S. Subcommission on Devonian Stratigraphy, 10, 18-19.

Golubtsov, V. K. 1997. Stratigraphy of the sedimentary cover of the western part of the East European Platform. In Geologiya i neftegazonosnost' zapada Vostochno-Evropejskoj platformy (Sinichka, A. M., ed.), pp. 48-104. Belaruskaya navuka, Minsk (in Russian).

Ivanov, A. O. 1990. Snetogorsk complex of ichthyofauna of the Main Devonian Field and its biostratigraphical significance. Vestnik Leningradskogo Univ., Ser. 7, Geol., Geogr., 1, 7 , 94-98 (in Russian).

Ivanov, A. \& Lukševičs, E. 1996. Late Devonian vertebrates of the Timan. Daba un muzejs, 6, 22-32.

Janvier, P. \& Blieck, A. 1993. The Silurian-Devonian agnathan biostratigraphy of the Old Red Continent. In Palaeozoic Vertebrate Biostratigraphy and Biogeography (Long, J. A., ed.), pp. 67-86. Belhaven Press, London (also published by John Hopkins Univ. Press, Baltimore, 1994).

Kajak, K. 1997. Upper Devonian. In Geology and Mineral Resources of Estonia (Raukas, A. \& Teedumäe, A., eds.), pp. 121-123. Estonian Academy Publishers, Tallinn.

Kalamees, K. 1988. Some Middle Devonian plants from Estonia. Proc. Acad. Sci. Estonian SSR. Geol., 37, 2, 83-88.

Karatajūtè-Talimaa, V. N. 1978. Telodonty silura i devona SSSR i Shpitzbergena. Mokslas, Vilnius (in Russian).

Kleesment, A. 1995. Lithological characteristics of the uppermost terrigenous Devonian complex in Estonia. Proc. Estonian Acad. Sci. Geol., 44, 4, 221-233. 
Kleesment, A. \& Mark-Kurik, E. 1997. Devonian: Introduction, Lower Devonian, Middle Devonian. In Geology and Mineral Resources of Estonia (Raukas, A. \& Teedumäe, A., eds.), pp. 107-121. Estonian Academy Publishers, Tallinn.

Kõrts, A. \& Mark-Kurik, E. 1997. Algae and vascular plants. In Geology and Mineral Resources of Estonia (Raukas, A. \& Teedumäe, A., eds.), pp. 213-218. Estonian Academy Publishers, Tallinn.

Kuršs, V. 1992. Devonskoe terrigennoe osadkonakoplenie na Glavnom devonskom pole. Zinatne, Riga (in Russian).

Lelièvre, H., Goujet, D., Blieck, A. \& Janvier, P. 1988. Poissons du Dévonien du Boulonnais (France). In Le Dévonien de Ferques, Bas-Boulonnais (N. France). PaléontologieSédimentologie-Stratigraphie-Tectonique (Brice, D., ed.). Biostratigraphie du Paléozoüque, 7, 503-522.

Loboziak, S., Streel, M. \& Weddige, K. 1991. Miospores, the lemurata and triangulatus levels and their faunal indices near the Eifelian/Givetian boundary in the Eifel (F.R.G.). Ann. Soc. Géol. Belg., 113, 2, 299-313.

Lukševičs, E. 1996. Bothriolepid antiarchs (Placodermi, Bothriolepididae) from the north-western part of the East European Platform. Dissertation work (summary). University of Latvia, Riga (in Latvian, English and Russian).

Lukševičs, E. \& Ivanov, A. 1996. Late Devonian placoderm zonation of the Main Devonian Field. In The Third Baltic Stratigraphical Conference. Abstracts. Field guide (Meidla, T., Puura, I., Nemliher, J., Raukas, A. \& Saarse, L., eds.), pp. 37-38. Tartu University Press, Tartu.

Lyarskaya, L. A. 1978. Zones and complexes of ichthyofauna in the Devonian of Latvia. In Ocherki geologii Latvii (Brangulis, A. P., ed.), pp. 64-76. Zinatne, Riga (in Russian).

Lyarskaya, L. A. 1981. Baltic Devonian Placodermi. Asterolepididae. Zinatne, Riga (in Russian, with English summary).

Lyarskaya, L. A. \& Lukševičs, E. V. 1992. Composition and distribution of agnathans and fishes in the Silurian and Devonian deposits of Latvia. In Paleontologiya $i$ stratigrafiya fanerozoya Latvii i Baltijskogo morya (Sorokin, V. S., ed.), pp. 46-62. Zinatne, Riga (in Russian).

Mark-Kurik, E. 1991. On the environment of Devonian fishes. Proc. Estonian Acad. Sci. Geol., 40, 3, 122-125.

Mark-Kurik, E. 1993. Givetian and the base of the Frasnian in the Baltic area. In Abstracts of the Second Baltic Stratigraphic Conference (Grigelis, A., Jankauskas, T.-R. \& Mertiniene, R., eds.), p. 57. The Geological Society of Lithuania, Vilnius.

Mark-Kurik, E. 1995. Devonian fish biostratigraphy in Baltic. Document submitted to the annual meeting of the Subcommission on Devonian Stratigraphy (IUGS), Paris, 8 Sept. 1995 (mimeographed).

Mark-Kurik, E. 1996. Stage boundary problems in the East Baltic Devonian. In The Third Baltic Stratigraphical Conference. Abstracts. Field guide (Meidla, T., Puura, I., Nemliher, J., Raukas, A. \& Saarse, L., eds.), pp. 39-41. Tartu University Press, Tartu.

Mark-Kurik, E. 1997. Devonian fishes. In Geology and Mineral Resources of Estonia (Raukas, A. \& Teedumäe, A., eds.), pp. 247-251. Estonian Academy Publishers, Tallinn.

Mark-Kurik, E. The Middle Devonian fishes of the Baltic States (Estonia, Latvia) and Belarus. Courier Forsch.-Inst. Senckenberg (in press).

Mark-Kurik, E., Märss, T. \& Kuršs, V. 1989. Excursion guidebook. The Silurian of Saaremaa and the Devonian of South Estonia and North Latvia. 2nd Intern. Colloq. Middle Paleozoic Fishes. Estonia, Latvia, September 1989. Eesti TA Toimetus- ja Kirjastusnõukogu, Tallinn.

Narbutas, V., Valiukevičius, J. \& Žeiba, S. 1993. Devonian stratigraphic scheme. In Catalogue of the Vendian-Devonian Stratotypes of Lithuania (Paškevičius, J., ed.), pp. 87-88. PMPP, Vilnius. 
Ovnatanova, N. S., Kuzmin, A. V., Obukhovskaya, T. G., Menner, V. V. \& Schuvalova, G. A. 1996. Upper Devonian high resolution stratigraphy of the East European Platform: correlation of regional stages, miospore and standard conodont zonation. In The Third Baltic Stratigraphical Conference. Abstracts. Field guide (Meidla, T., Puura, I., Nemliher, J., Raukas, A. \& Saarse, L., eds.), p. 48. Tartu University Press, Tartu.

Rodionova, G. D. \& Umnova, V. T. 1997. Fluctuation of the Devonian sea level in the Moscow Basin. Stratigrafiya. Geologicheskaya korrelyatsiya, 5, 2, 21-28 (in Russian).

Sorokin, V. S. (ed.). 1981. Devon i karbon Pribaltiki. Zinatne, Riga (in Russian).

Sorokin, V. 1996. Correlation problems of the Latvian and East Baltic Upper Devonian stratigraphic units with the standard conodont zonation. In The Third Baltic Stratigraphical Conference. Abstracts. Field guide (Meidla, T., Puura, I., Nemliher, J., Raukas, A. \& Saarse, L., eds.), pp. 62-63. Tartu University Press, Tartu.

Steinmann, J. \& Sarv, L. 1951. Küllatova kuumuskindlate savide geoloogilise uurimise aruanne. Eesti NSV TA Geoloogiliste Teaduste Instituut, Tallinn (unpublished manuscript in the Archives of the Estonian Acad. Sci.).

Streel, M., Higgs, K., Loboziak, S., Riegel, W. \& Steemans, P. 1987. Spore stratigraphy and correlation with faunas and floras in the type marine Devonian of the Ardenne-Rhenish regions. Rev. Palaeobot. Palynol., 50, 211-229.

Thomson, P. W. 1940. Beitrag zur Kenntnis der fossilen Flora des Mitteldevons in Estland. Tartu Ülikooli j.o. Loodusuurijate Seltsi Aruanded, 45, 1-4, 195-216.

Valiukevičius, J. 1994. Acanthodian zonal sequence of Early and Middle Devonian in the Baltic Basin. Liet. aukšt. m-lu mokslo darbai. Geologija, 17, 115-125.

Walliser, O. H., Bultynck, P., Weddige, K., Becker, R. T \& House, M. R. 1995. Definition of the Eifelian-Givetian stage boundary. Episodes, 18, 3, 107-115.

Yurina, A. L. 1988. Middle and Late Devonian flora of northern Eurasia. Trudy Paleont. Inst. AN SSSR, 227 (in Russian).

Žeiba, S. 1994. On stratigraphy and correlation of the Upper Frasnian sections in Lithuania. Liet. aukšt. m-lu mokslo darbai. Geologija, 17, 126-131.

Žeiba, S. \& Valiukevičius, J. 1972. Neue Angaben über die Konodontenfauna des Famens in südlichen Balticum. Liet. TSR aukšt. m-lu mokslo darbai. Geogr. ir geol., 9, 167-171 (in Russian, with Lithuanian and German abstracts).

\title{
LODE KIHISTIKU (GAUJA KIHISTU) MIOSPOORIDE KOOSLUS EESTIS NING KESK- JA ÜLEMDEVONI PIIRI PROBLEEM
}

\author{
Elga MARK-KURIK, Alain BLIECK, Stanislas LOBOZIAK \\ ja Anne-Marie CANDILIER
}

Proovist, mis pärineb endisest Küllatova rasksulava savi leiukohast KaguEestis, on kindlaks tehtud miospooride kooslus, mis vastab oma koosseisu poolest Ida-Euroopa platvormi Ancyrospora incisa-Geminospora micromanifesta (IM) alamtsooni omale. Nimetatud kooslus annab võimaluse korreleerida Gauja kihistut ligikaudu sama vanusega stratigraafiliste üksustega Baltikumi naaberaladelt. Valgevenes on selleks üksuseks Lani lademe Ubordi kihid, Moskva basseinis aga Pašija lade. Saadud korrelatsiooni alusel võib Gauja kihistut pidada keskdevoni vanuseks. Kesk- ja ülemdevoni piir paikneb nähtavasti nimetatud kihistu ülemise piiri lähedal, kuid siiski sellest mõnevõrra kõrgemal. 


\title{
КОМПЛЕКС МИОСПОР ЛОДЕСКОЙ ПАЧКИ (ГАУЙСКАЯ СВИТА) \\ В ЭСТОНИИ И ПРОБЛЕМА СРЕДНЕ- И ВЕРХНЕДЕВОНСКОЙ ГРАНИЦЫ
}

\author{
Эльга МАРК-КУРИК, Ален БЛИК, Станислас ЛОБОЗяК \\ и Анне-Марие КАНДИЛЕР
}

В образце тугоплавких глин из старого карьера Кюллатова (ЮгоВосточная Эстония) установлен комплекс миоспор, который по своему составу аналогичен ассоциации подзоны Ancyrospora incisa-Geminospora micromanifesta (IM) Восточно-Европейской платформы. Этот комплекс миоспор позволяет скоррелировать гауйскую свиту с примерно одновозрастными стратиграфическими подразделениями смежных регионов Прибалтики. В Беларуси гауйской свите соответствуют убортские слои ланского горизонта, а в Московском бассейне - пашийский горизонт. Согласно этой корреляции, гауйская свита имеет, вероятно, среднедевонский возраст. Граница между средним и верхним девоном проходит вблизи верхов этой свиты или, возможно, несколько выше ее. 